\title{
SISTEM KEAMANAN PINTU KAMAR KOS MENGGUNAKAN FACE RECOGNITION DENGAN TELEGRAM SEBAGAI MEDIA MONITORING DAN CONTROLLING
}

\author{
Erviansyah Fadly, Suryo Adi Wibowo, Agung Panji Sasmito \\ Program Studi Teknik Informatika S1, Fakultas Teknologi Industri \\ Institut Teknologi Nasional Malang, Jalan Raya Karanglo km 2 Malang, Indonesia \\ 1718012@scholar.itn.ac.id
}

\begin{abstract}
ABSTRAK
Tindak kejahatan pencurian akhir - akhir ini banyak dijumpai di masyarakat. Terlebih lagi dengan adanya pandemi Covid-19 sering terjadi pencurian khususnya di lingkungan kos karena sudah lama tidak ditinggali oleh pemiliknya, dan juga keamanan dari pintu kamar kos yang relatif rendah ditambah lagi tidak adanya penjagaan seperti kamera pengawas yang dipasang diarea kos. Dengan banyaknya kasus tersebut membuat penghuni kamar kos merasa tidak tenang dengan kondisi kamar yang ditinggalkan. Face recognition merupakan salah satu teknik pengenalan wajah yang sama seperti sidik jari dan retina mata, dimana hasil tangkapan kamera akan dicocokkan dengan tekstur lekuk wajah yang sudah ada. Oleh karena itu, melalui penelitian ini bermaksut untuk membuat sebuah smarthome dengan ditambah sistem monitoring yang dirancang untuk memantau dari jarak jauh dan meminimalisir tindak pencurian. Setelah dilakukan pengujian pada penelitian ini menghasilkan sebuah perangkat keras maupun perangkat lunak pada program yang telah dibuat, sistem monitoring melalui aplikasi telegram dapat menunjukan bahwa notifikasi berhasil terkirim dengan waktu respon $6-8$ detik. Pada pengujian perangkat keras didapatkan bahwa sensor ultrasonic menunjukan tingkat keakuratan untuk mendeteksi hingga $89 \%$, berdasarkan pengujian pada ESP32-CAM dapat mendeteksi wajah dengan tingkat keakuratan hingga 90\%, adapun pengujian pada sensor RFID sebagaimana diperuntukan bilamana ESP32-CAM mengalami kegagalan sistem, sensor RFID dapat mendeteksi E-KTP sangat baik dengan tingkat keakuratan 100\%.
\end{abstract}

Kata Kunci : Face Recognition, ESP32-CAM, Telegram, Internet of Things

\section{PENDAHULUAN}

Kost adalah tinggal di rumah orang lain tanpa makan, dengan membayar setiap bulannya (Poerwadarminta, 2003). Rumah kos merupakan salah satu tempat hunian yang identik dengan mahasiswa baru yang sedang menempuh pendidikan jauh dari kampung halaman. Mahasiswa baru biasanya akan tinggal di sebuah salah satu rumah di masyarakat yang menyediakan sebuah kamar yang memang khusus disewakan bagi mahasiswa baru yang ingin menyewa selama menempuh pendidikan (Rosadi dan Andriawan, 2016).

Tindak kejahatan pencurian akhir - akhir ini banyak dijumpai di masyarakat (Suharyoso, 2014). Terlebih lagi dengan adanya pandemi Covid-19 sering terjadi pencurian khususnya di lingkungan kos karena sudah lama tidak ditinggali oleh pemiliknya. Para pencuri memanfaatkan momen tersebut dengan sangat mudah mencuri barang berharga dari sang pemilik kamar karena keamanan dari pintu kamar kos yang relatif rendah dan ditambah lagi tidak adanya penjagaan seperti kamera pengawas yang dipasang diarea kos. Dengan banyaknya kasus tersebut membuat penghuni kamar kos merasa tidak tenang dengan kondisi kamar yang ditinggalkan.

Face recognition merupakan salah satu teknik pengenalan wajah yang sama seperti sidik jari dan retina mata, dimana hasil tangkapan kamera akan dicocokkan dengan tekstur lekuk wajah yang sudah ada. (Aryani, dkk 2017). Oleh karena itu, dengan adanya teknik tersebut perlu adanya inovasi yang dapat diterapkan pada masalah terkait keamanan kamar agar lebih dimudahkan dengan bantuan teknologi.

Satu konsep yang dapat diterapkan dalam sistem keamanan adalah Internet of Things (IoT). Internet of Things merupakan salah satu teknologi yang erat hubunganya dengan revolusi industri 4.0 ini seperti kesehatan, rumah, pertanian dan industri lainnya (Rauf, 2018). Dengan adanya IoT, kegiatan manusia seperti memantau keamanan kamar dapat di laksanakan secara jarak jauh. Oleh karena itu, melalui penelitian ini bermaksut untuk membuat sebuah smarthome dengan ditambah sistem monitoring yang dirancang untuk memantau dari jarak jauh dan meminimalisir tindak pencurian. Berdasarkan pemaparan tersebut, peneliti berinovasi dengan menggagas penelitian terkait Sistem Keamanan Pintu Kamar Kos Menggunakan Face Recognition Dengan Telegram Sebagai Media Monitoring Dan Controlling.

\section{TINJAUAN PUSTAKA}

2.1. Penelitian Terdahulu

Peneliti Rahmadhan, (2020). Dalam judul "Rancang Bangun Akses Kunci Pintu Gerbang Indekos Menggunakan E-KTP (Elektronik Kartu Tanda Penduduk) Berbasis Mikrokontroller", 
penelitian ini bertujuan untuk merancang sistem keamanan pada pintu gerbang indekos. Penelitian ini menghasilkan suatu alat yang dapat meningkatkan keamanan pada akses gerbang masuk kos dengan menggunakan E-KTP untuk akses masuknya. Alat ini dirancang layaknya fitur NFC (Near Field Communication), dengan memanfaatkan sensor RFID untuk memindai E-KTP, E-KTP tersebut sebagai alat ganti NFC untuk mengakses Selenoid DoorLock agar pintu gerbang kos dapat terbuka, terdapat Buzzer sebagai notifikasi peringatan dan $L C D$ sebagai alat monitoring jika auntetikasi tidak berhasil.

Penelitian Wibowo, dkk (2019). Dalam judul "Ruang Kuliah Pintar Pemantau Tingkat Efektivitas Pembelajaran Yang Dapat Mendeteksi Mahasiswa Bosan Dan Mengantuk", penelitian ini bertujuan untuk memonitoring tingkat efektifitas pembelajaran dengan mendeteksi ekspresi wajah mahasiswa yang terlihat bosan dan mengantuk. Penelitian ini menghasilkan suatu alat yang juga dilengkapi dengan sistem presensi menggunakan RFID. Alat ini juga berbasiskan Internet of Things, yang artinya data presensi yang sudah dimasuk dapat dilihat secara realtime oleh guru, siswa dan bahkan orang tua, sehingga presensi dapat dipantau dari mana saja dan kapan saja.

Penelitian Setiawan dan Purnamasari, (2019). Dalam judul "Pengembangan Smart Home dengan Microcontrollers ESP32 Dan MC-38 Door Magnetic Switch Sensor Berbasis Internet of Things (IoT) Untuk Meningkatkan Deteksi Dini Keamanan Perumahan", penelitian ini bertujuan untuk membangun sistem keamanan pada perumahan pada saat ditinggal oleh penghuninya. Penelitian ini menghasilkan suatu alat yang dapat mendeteksi dini suatu aksi pencurian pada rumah atau jendela berhasil didobrak secara paksa maka secara otomatis sistem pada alat ini mengirimkan suatu hasil foto. Alat ini di rancang dan diprogram melalui Arduino IDE untuk memanfaatkan Smart Home dan Microcontroller ESP32 yang menyatu dengan kamera dan MC-38 door magnetic switch sensor yang kemudian digunakan untuk merespon kamera. Secara teknis alat ini akan berkerja jika mengirimkan sinyal gambar seseorang yang tidak dikenal dan yang masuk secara tidak secara wajar, kemudian gambar tersebut bisa diakses melalui website dan smartphone.

Penelitian Wicaksono dan Rahmatya, (2020). Dalam judul "Implementasi Arduino dan ESP32 CAM untuk Smart Home", penelitian ini bertujuan untuk memonitor keamanan rumah. Penelitian ini menghasilkan suatu alat yang dapat memantau aktifitas dan keamanan rumah. Jika ada suatu gerakan terdeteksi maka sensor PIR dan ESP32 CAM akan mendeteksi secara otomatis. Alat ini menggunakan Arduino sebagai microcontroller dan juga berbasis Internet of Things, yang artinya akan sangat mudah dikontrol dan dipantau melalui jarak jauh menggunakan aplikasi Line pada smartphone pengguna.
Penelitian Zuhri dan Ihkwan, (2020). Dalam judul "Perancangan Sistem Keamanan Ganda Brangkas Berbasis Telegram Menggunakan Mikrokontroler ESP32-CAM". Penelitian ini bertujuan untuk mengembangkan inovasi sistem keamanan pada brangkas yang biasanya hanya menggunakan sistem kunci ganda. Penelitian ini menghasilkan suatu alat atau sistem dengan memamfaatkan ESP32 sebagai kamera deteksi dan sensor PIR untuk mendeteksi suatu gerakan. Alat ini juga berbasiskan Internet of Things yang artinya alat ini dapat dipantau melalui jarak jauh dengan memanfaatkan fitur notifikasi pada media Aplikasi Telegram dan penyimpanan gambar otomatis melalui google drive.

\subsection{Dasar Teori}

\subsubsection{Face Recognition}

Teknologi face recognition adalah suatu aplikasi komputer yang digunakan untuk mengidentifikasikan dan memverifikasi wajah dari gambar ataupun wajah yang sesungguhnya, dengan membandingkan yang telah diseleksi dari sebuah sample yang disimpan disistem yang sudah disediakan (Purwanto, 2015).

Teknologi face recognition dikembangkan dalam bidang keamanan untuk inovasi pada sistem keamanan yang relatif rendah, seperti contoh yang hanya menggunakan kata kunci. Karena pada setiap wajah manusia memiliki struktur yang berbeda satu sama lain, maka dari itu sangat memungkinkan jika struktur wajah tersebut digunakan sebagai auntetikasi pada sistem.

\subsubsection{Konsep Face Recognition}

Dalam konsep pengenalan wajah atau face recognition, pengenalan wajah merupakan salah satu metode yang berbasiskan suatu wajah. Setelah sampel yang disimpan dalam suatu sistem, identifikasi dibagi menjadi dua bagian yaitu dikenali atau tidak dikenali (Ni Wayan Marti, 2010).

Di balik kemudahan pengenalan wajah, mungkin terdapat beberapa masalah dalam proses pengenalan wajah, yaitu perubahan skala, perubahan posisi, perubahan cahaya, atau perubahan detail dan ekspresi wajah (Ni Wayan Marti, 2010).

\subsubsection{ESP32-CAM}

ESP32-CAM adalah papan pengembangan WiFi /Bluetooth dengan mikrokontroler ESP32 dan kamera. Mikrokontroller ini menyediakan fitur yang dapat digunakan siapa saja, atau bisa dikatakan open source, salah satu fiturnya yaitu digunakan untuk mengambil gambar, pengenalan wajah dan deteksi wajah. Mikrokontroller tersebut bisa digunakan menggunakan pada arduino ide untuk memanfaatkan library atau fitur yang sudah disediakan. 


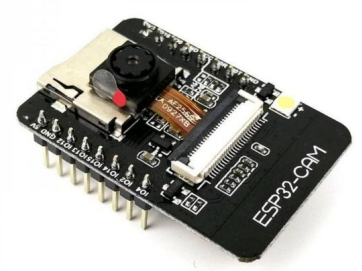

Gambar 1. ESP32-CAM

\subsubsection{NodeMCU 8266}

NodeMCU adalah platform IoT sumber terbuka atau open source. Terdiri dari perangkat keras dalam bentuk sistem-on-chip ESP8266. ESP8266 yang diproduksi oleh Espressif, dan firmware yang digunakan, menggunakan bahasa pemrograman skrip Lua. Secara default, istilah NodeMCU sebenarnya mengacu pada firmware yang digunakan sebagai pengganti kit pengembangan perangkat keras. NodeMCU dapat mirip dengan papan pengembangan Arduino ESP8266. (Sumardi, 2016).

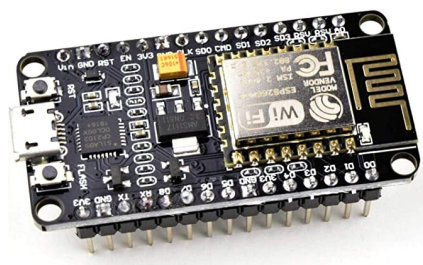

Gambar 2. NodeMCU 8266

\subsubsection{RFID MFRC522}

RFID dikembangkan sebagai pengganti atau inovasi dari teknologi barcode. Tag RFID tersusun dari sebuah microchip yang dilengkapi antenna yg dipasang dalam sebuah kartu. Dan untuk membaca kartu tersebut diperlukan sebuah piranti pembaca yang akan memancarkan gelombang radio dan menangkap sinyal tanggapan yang dipancarkan dari kartu (Hidajanto Djamal, 2014).

Kelebihan RFID adalah relatif lebih cepat, ukuran lebih kecil sehingga praktis dan proses pemindaian tidak memerlukan kontak langsung dengan reader.

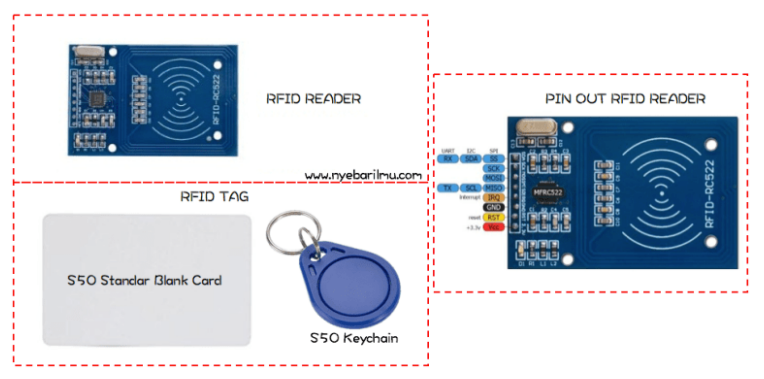

Gambar 3. Sensor RFID MRFC522

\subsubsection{Sensor Ultrasonic}

Sensor ultrasonik adalah sensor yang bekerja berdasarkan prinsip pantulan gelombang suara, dimana sensor ini menghasilkan gelombang suara yang kemudian menangkapnya kembali dengan perbedaan waktu sebagai dasar penginderaannya.

Perbanding lurus dengan jarak atau tinggi objek yang memantulkannya. Jenis objek yang dapat diindera diantarannya adalah: objek padat, cair, butiran, maupun tekstil (Hani, 2010).

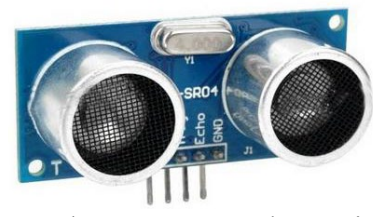

Gambar 4. Sensor Ultrasonic

\subsubsection{Relay}

Relay adalah komponen elektronika yang berupa saklar atau switch elektrik yang di operasikan menggunakan listrik. Relay biasa disebut sebagai komponen electromechanical atau elektromekanikal yang terdiri dari dua bagian utama yaitu coil atau elektromagnet dan kontak saklar atau mekanikal Relay elektromekanis ini juga didefinisikan sebagai saklar yang digerakkan secara mekanis oleh daya atau energi listrik (Dickson, 2017).

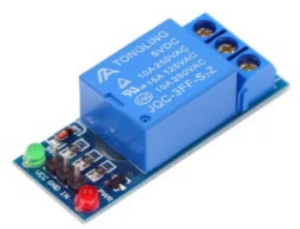

Gambar 5. Relay

\subsubsection{Selenoid Doorlock}

Selenoid digunakan sebagai akuator. Biasanya alat ini digunakan untuk kunci pintu otomatis. Ketika tegangan diberikan, solenoid akan bergerak atau bekerja. Tegangan rata-rata solenoid ini bekerja pada tegangan 12 volt, tetapi ada juga yang 6 volt dan 24 volt. Prinsip kerja dari solenoid door lock itu sendiri adalah pada keadaan normal, solenoid valve berada pada posisi tuas memanjang atau terkunci, jika diberi tegangan maka tuas akan membuka atau memendek. (Pratama, 2015).

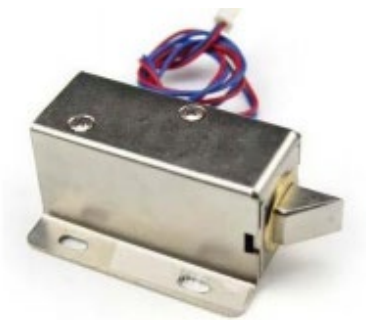

Gambar 6. Selenoid Doorlock 


\subsubsection{Internet of Things}

Internet of Thing (IoT) adalah sebuah konsep dimana suatu objek yang memiliki kemampuan untuk mentransfer data melalui jaringan tanpa memerlukan interaksi manusia ke manusia atau manusia ke komputer, penggunaan IoT dapat terapkan pada berbagai hal salah satunya adalah bidang industri, kesehatan, dan sebagainya (Dewaweb, 2021).

\subsubsection{Indekos}

Menurut Kamus Besar Bahasa Indonesia, IndeKos adalah tinggal dirumah orang lain dengan atau tanpa makan atau meng-in-de-koskan adalah menumpangkan seseorang tinggal dan makan dengan membayar. Dapat disimpulkan bahwa pemilik rumah indekos adalah orang pribadi atau badan yang memiliki rumah, kamar, atau bangunan, yang disewakan kepada pihak lain sebagai tempat tinggal/pemondokan dan mengenakan pembayaran sebagai imbalan dalam jumlah tertentu serta periode waktu pembayaran tertentu.

\subsubsection{E-KTP}

E-KTP merupakan sebuah kartu identitas sah warga Negara Indonesia, Dengan majunya teknologi yang semakin pesat, E-KTP sudah mengalami perubahan yang sangat signifikan. Untuk saat ini EKTP atau kepanjangan dari Elektronik Kartu Tanda Penduduk sudah menggunakan smartcard dan berbasiskan nomor induk kependudukan.

\subsubsection{Telegram}

Telegram Messenger adalah sebuah aplikasi layanan pesan seperti layaknya Whatsapp, Line dan lainnya. Telegram pun juga tak hanya berbagi pesan, namun juga bisa berbagi foto, video, location tagging antar pengguna.

Banyak keunggulan Telegram dibanding aplikasi layanan pesan lainnya. Salah satunya yaitu Telegram Bot, telegram menyediakan fitur membuat Bot pada aplikasinya. Fitur bot tersbut dapat terintegrasi langsung dengan berbagai layanan melalui internet dan banyak sekali bot-bot bermanfaat yang dapat digunakan pada aplikasi Telegram.

\subsubsection{Smarthome}

Rumah Cerdas (Smart Home) adalah aplikasi gabungan antara teknologi dan pelayanan yang dikhususkan pada lingkungan rumah dengan fungsi tertentu yang bertujuan meningkatkan keamanan, efisiensi dan kenyamanan penghuninya. Sistem rumah pintar (smart home) biasanya terdiri dari perangkat monitoring, perangkat kontrol dan otomatis ada beberapa perangkat yang dapat di akses menggunakan komputer (Tri Fajar Yurmama, 2009).

\subsubsection{Website}

Website adalah kumpulan halaman web yang dapat diakses publik dan saling terkait yang berbagi satu nama domain. Website dapat dibuat dan dikelola oleh individu, grup, bisnis, atau organisasi untuk melayani berbagai tujuan. Bersama-sama, semua website yang dapat diakses publik membentuk World Wide Web (Mardatila, 2021).

\section{METODE PENELITIAN}

3.1. Analisa Kebutuhan

3.1.1 Kebutuhan Fungsional

Adapun kebutuhan fungsional yang dibutuhkan pada sistem keamanan pintu kamar kos adalah :

1. Sistem mempunyai fitur untuk memindai wajah.

2. Sistem mempunyai fitur untuk memindai E-KTP.

3. Sistem mempunyai fitur untuk menangkap gambar.

4. Sistem mampu mengirim notifikasi pada pemilik kamar.

5. Sistem mampu memantau situasi dan kondisi depan pintu kamar.

\subsubsection{Kebutuhan Non Fungsional}

Kebutuhan nonfungsional antarmuka pemakai meliputi :

1. Alat dan website dapat diakses secara realtime.

2. Alat dengan website harus terkoneksi jaringan internet.

3. Website dapat diakses menggunakan browser seperti Google Chrome, Mozila Firefox, dll

\subsection{Diagram Blog Sistem}

ESP32-CAM akan aktif jika sensor ultrasonic mendeteksi seseorang didepan pintu lebih dari waktu yang ditentukan, dan secara otomatis kamera akan memindai wajah dan memproses jika wajah tersebut sudah terdaftar atau tidak, jika mengalami kegagalan sistem pada ESP32-CAM dapat menggunakan E-KTP sebagai akses masuk dengan bantuan Sensor RFID.

Solenoid doorlock digunakan untuk menutup dan membuka pintu, doorlock akan otomatis terbuka jika kamera mendeteksi wajah yang sudah terdaftar. Dan termonitoring dengan media aplikasi Telegram. Proses kerja pada alat ini di tunjukkan pada Gambar 7

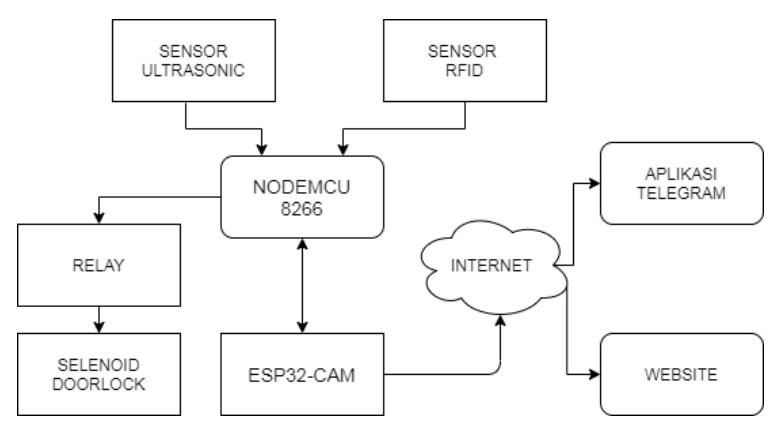

Gambar 7. Blok Diagram Sistem 


\subsection{Flowchart Sistem}

Adapun alur proses flowchat sistem dijelaskan pada gambar 8 .

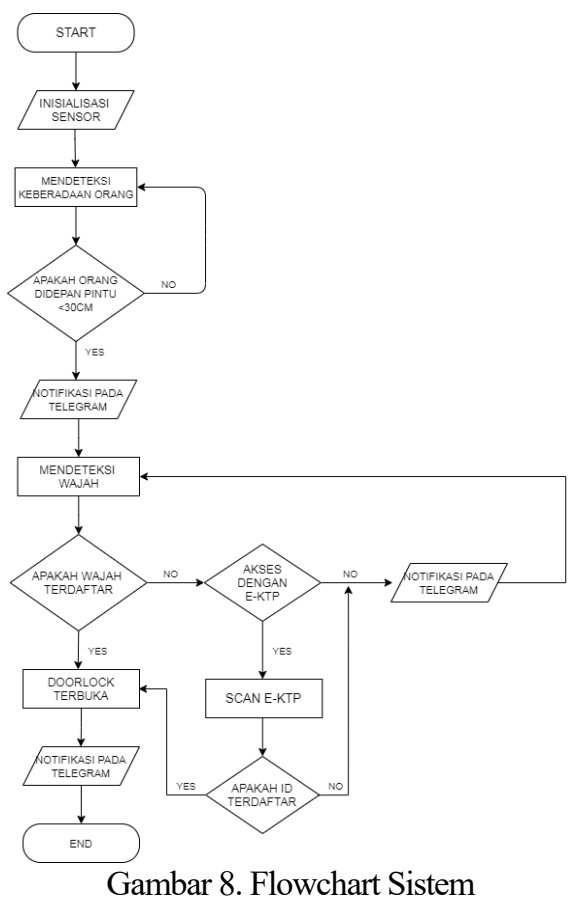

Berdasarkan flowchart pada Gambar 8, Pertama menginisialisasi sensor lalu sistem akan mendeteksi keberadaan seseorang didepan pintu, jika ada seseorang didepan pintu kurang dari $30 \mathrm{~cm}$ maka aka nada notifikasi pada telegram. Jika tidak maka akan tetap mendeteksi keberadaan seseorang.

\section{HASIL DAN PEMBAHASAN}

\subsection{Implementasi Sistem}

Implementasi dari sistem keamanan pintu kamar kos berbasis internet of things yang di rancang, yaitu meliputi implementasi pengenalan wajah dengan memanfaatkan fitur pada ESP32-CAM, tampilan notifikasi telegram dan website, dan tampilan perangkat keras.

\subsection{Halaman Fitur ESP32-CAM}

Tampilan fitur pada ESP32-CAM yang menyediakan webserver untuk sistem pengenalan wajah. Pada halaman terdapat live streaming yang secara langsung terkoneksi dengan ESP32-CAM, yang nantinya digunakan untuk mendaftarkan beberapa wajah. Tampilan halaman dapat ditunjukkan pada Gambar 9.

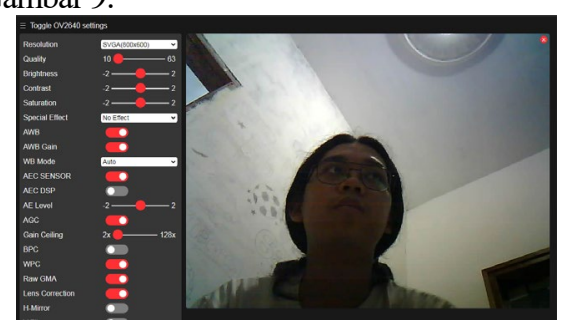

Gambar 9. Tampilan Fitur ESP32-CAM

\subsection{Halaman Sistem Pengenalan Wajah}

Tampilan fitur pada ESP32-CAM yang menyediakan webserver untuk sistem pengenalan wajah. Pada halaman ini sistem akan secara langsung mendeteksi wajah yang sebelumnya sudah didaftarkan dan terdapat notifikasi bahwa wajah sudah terdaftar atau tidak. Tampilan halaman dapat ditunjukkan pada Gambar 10.

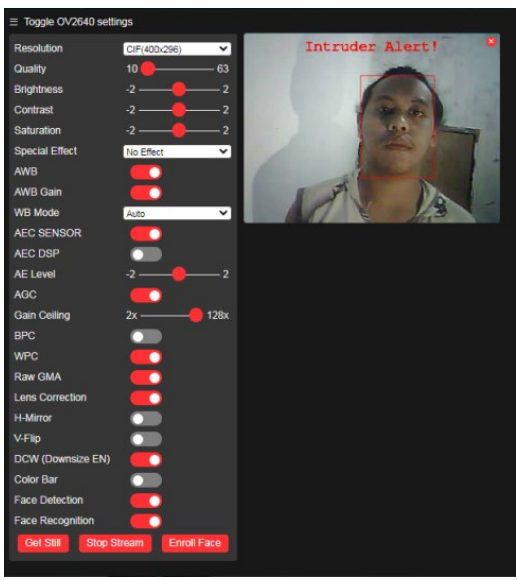

Gambar 10. Tampilan Sistem Pengenalan Wajah

\subsection{Tampilan Notifikasi Telegram}

Notifikasi telegram akan masuk ketika user menambahkan perintah OPEN pada bot, maka solenoid akan terbuka secara manual, dan menambahkan notifikasi bila pintu sudah terbuka. Perintah foto untuk memberikan perintah ESP32CAM untuk menjepret dan foto tersebut akan dikirim melalui telegram. Tampilan Telegram dapat ditunjukkan pada Gambar 11.

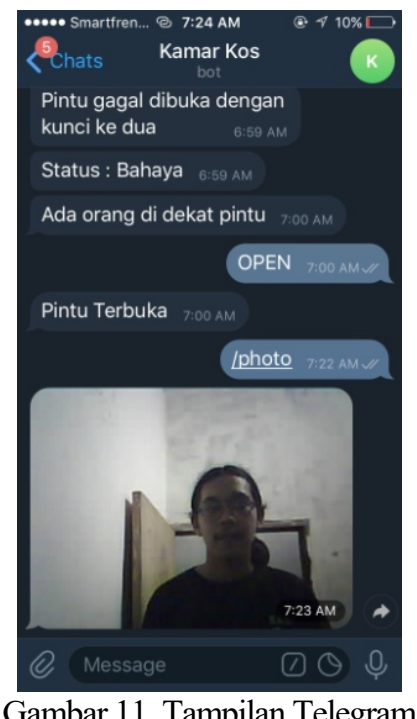

\subsection{Halaman Live Streaming}

Halaman index adalah halaman yang berfungsi untuk menampilkan halaman utama pada website yang dibuat. Halaman utama pada website yang dibuat untuk fitur live streaming. 

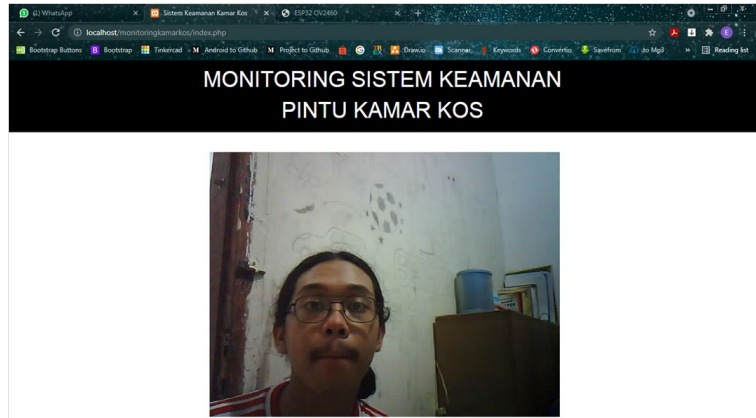

Gambar 12. Tampilan Live Streaming

\subsection{Pengujian Hardware}

Prototype yang dibangun terdiri dari ESP32CAM yang berfungsi untuk akses utama membuka pintu dengan menggunakan deteksi wajah, dan juga sensor RFID yang berfungsi untuk membuka kamar dengan e-ktp bila mana ESP32-CAM mengalami error system. Hasil implementasi perangkat keras tersebut merupakan implementasi sistem keamanan pintu kamar kos. Tampilan dapat ditunjukkan pada Gambar 12.

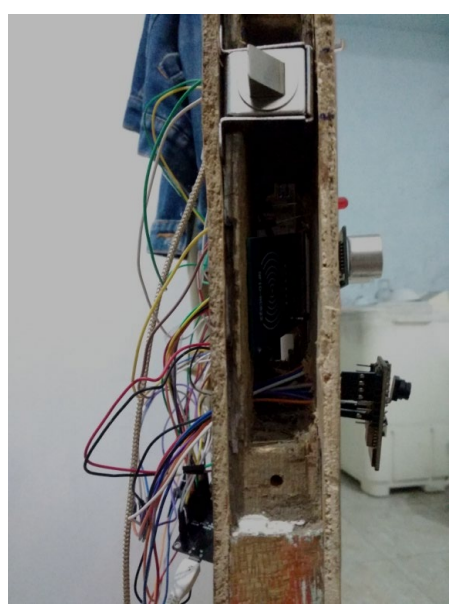

Gambar 13. Tampilan Implementasi Hardware

\subsection{Pengujian Notifikasi Telegram}

Pengujian notifikasi telegram yang dilakukan pada penelitian ini berfungsi untuk melihat tingkat keberhasilan serta respon time yang diperlukan oleh sistem. Pengujian notifikasi telegram ditunjukkan pada Tabel 1.

Tabel 1. Pengujian Notifikasi Telegram

\begin{tabular}{|c|c|c|}
\hline $\begin{array}{c}\text { Pengujiar } \\
\text { Ke - }\end{array}$ & $\begin{array}{c}\text { Berhasil Terkirim } \\
\text { /Tidak }\end{array}$ & $\begin{array}{c}\text { Waktu Respon } \\
\text { Notifikasi }\end{array}$ \\
\hline 1 & Berhasil Terkirim & 8 Detik \\
\hline 2 & Berhasil Terkirim & 7 Detik \\
\hline 3 & Berhasil Terkirim & 7 Detik \\
\hline 4 & Berhasil Terkirim & 7 Detik \\
\hline 5 & Berhasil Terkirim & 6 Detik \\
\hline 6 & Berhasil Terkirim & 6 Detik \\
\hline 7 & Berhasil Terkirim & 6 Detik \\
\hline 8 & Berhasil Terkirim & 8 Detik \\
\hline 9 & Berhasil Terkirim & 8 Detik \\
\hline 10 & Berhasil Terkirim & 8 Detik \\
\hline
\end{tabular}

Berdasarkan hasil pengujian pada tabel 1 menunjukan setelah melakukan 10 kali percobaan bahwa notifikasi telegram yang berhasil terkirim terdapat sedikit perbedaan waktu respon direntan 6-8 detik.

\subsection{Hasil Pengujian ESP32-CAM}

Pengujian ESP32-CAM dilakukan dengan cara melihat pada fitur webserver pada ESP32-CAM dan membandingkan hasil deteksi dari 10 wajah. Pengujian pengenalan wajah ditunjukkan pada tabel 2 .

Tabel 2. Pengujian ESP32-CAM

\begin{tabular}{|c|c|c|c|c|}
\hline ESP32-CAM & Cocok / Tidak & Pintu & Error & Akurasi \\
\hline Wajah 1 & Cocok & Terbuka & $0 \%$ & $100 \%$ \\
\hline Wajah 2 & Cocok & Terbuka & $100 \%$ & $0 \%$ \\
\hline Wajah 3 & Tidak & Tertutup & $0 \%$ & $100 \%$ \\
\hline Wajah 4 & Tidak & Tertutup & $0 \%$ & $100 \%$ \\
\hline Wajah 5 & Tidak & Tertutup & $0 \%$ & $100 \%$ \\
\hline Wajah 6 & Tidak & Tertutup & $0 \%$ & $100 \%$ \\
\hline Wajah 7 & Tidak & Tertutup & $0 \%$ & $100 \%$ \\
\hline Wajah 8 & Tidak & Tertutup & $0 \%$ & $100 \%$ \\
\hline Wajah 9 & Tidak & Tertutup & $0 \%$ & $100 \%$ \\
\hline Wajah 10 & Tidak & Tertutup & $0 \%$ & $100 \%$ \\
\hline
\end{tabular}

Berdasarkan hasil pengujian pada tabel 2 terdapat 1 wajah yang sudah didaftarkan, dan menunjukan setelah melakukan 10 kali pengujian dengan wajah yang berbeda, terdapat kegagalan sistem dengan indikasi keindentikan pada wajah pada percobaan ke 2. Pada pengujian ini dapat disimpulkan ESP32-CAM dapat mendeteksi wajah dengan tingkat akurasi $90 \%$.

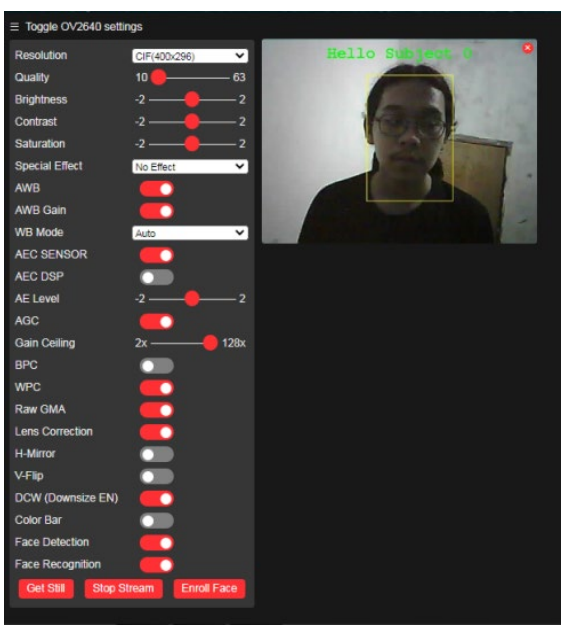

Gambar 14. Tampilan Pengenalan Wajah

\subsection{Pengujian Sensor RFID}

Pengujian sensor RFID dilakukan dengan melihat pada fitur serial monitor pada Arduino IDE dan membandingkan hasil deteksi dari 10 E-KTP. Pengujian perbandingan E-KTP ditunjukkan pada Tabel 3. 
Tabel 3. Pengujian E-KTP

\begin{tabular}{|c|c|c|c|c|}
\hline E- KTP & $\begin{array}{c}\text { Terdaftar } \\
\text { / Tidak }\end{array}$ & Pintu & Error & Akurasi \\
\hline E- KTP 1 & Terdaftar & Terbuka & $0 \%$ & $100 \%$ \\
\hline E- KTP 2 & Tidak & Tertutup & $0 \%$ & $100 \%$ \\
\hline E- KTP 3 & Tidak & Tertutup & $0 \%$ & $100 \%$ \\
\hline E- KTP 4 & Tidak & Tertutup & $0 \%$ & $100 \%$ \\
\hline E- KTP 5 & Tidak & Tertutup & $0 \%$ & $100 \%$ \\
\hline E- KTP 6 & Tidak & Tertutup & $0 \%$ & $100 \%$ \\
\hline E- KTP 7 & Tidak & Tertutup & $0 \%$ & $100 \%$ \\
\hline E- KTP 8 & Tidak & Tertutup & $0 \%$ & $100 \%$ \\
\hline E- KTP 9 & Tidak & Tertutup & $0 \%$ & $100 \%$ \\
\hline E-KTP 10 & Tidak & Tertutup & $0 \%$ & $100 \%$ \\
\hline
\end{tabular}

Berdasarkan hasil pengujian pada tabel 3 terdapat 1 E-KTP yang sudah didaftarkan, dan menunjukan setelah melakukan 10 kali pengujian dengan E-KTP yang berbeda, Pada pengujian ini dapat disimpulkan bahwa sensor RFID dapat mendeteksi E-KTP dengan tingkat akurasi 100\%.

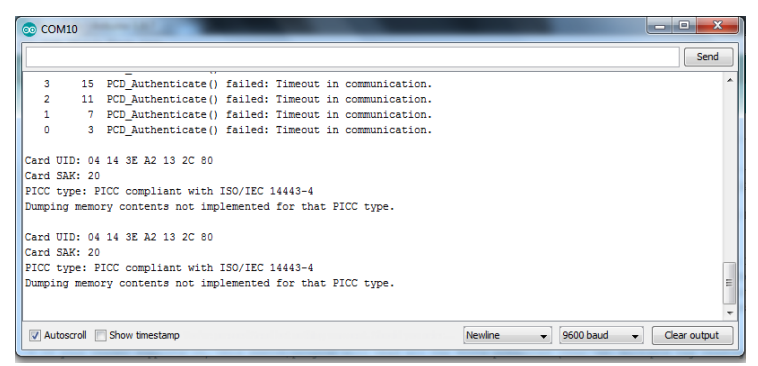

Gambar 15. Tampilan UID E-KTP

\subsection{Pengujian Sensor Ultrasonic}

Pengujian sensor ultrasonic dilakukan untuk mengetahui perbandingan jarak yang dihasilkan sensor ultrasonic dengan objek nyata. Pengujian perbandingan sensor ultrasonic dapat dilihat di Tabel 4.

Tabel 4. Pengujian Sensor Ultrasonic

\begin{tabular}{|c|c|c|c|c|}
\hline $\begin{array}{c}\text { Pengujian } \\
\text { Ke - }\end{array}$ & $\begin{array}{c}\text { Sensor Ultra } \\
\text { sonic }\end{array}$ & Objek & Berhasil & Selisih \\
\hline 1 & $10 \mathrm{~cm}$ & $10 \mathrm{~cm}$ & Berhasil & $0 \mathrm{~cm}$ \\
\hline 2 & $15 \mathrm{~cm}$ & $15 \mathrm{~cm}$ & Berhasil & $0 \mathrm{~cm}$ \\
\hline 3 & $20 \mathrm{~cm}$ & $20 \mathrm{~cm}$ & Berhasil & $0 \mathrm{~cm}$ \\
\hline 4 & $25 \mathrm{~cm}$ & $25 \mathrm{~cm}$ & Berhasil & $0 \mathrm{~cm}$ \\
\hline 5 & $30 \mathrm{~cm}$ & $30 \mathrm{~cm}$ & Berhasil & $0 \mathrm{~cm}$ \\
\hline
\end{tabular}

Berdasarkan tabel 4 dapat terlihat bahwa pengujian untuk deteksi sensor ultrasonic dapat berhasil sampai 5 pengujian, menunjukkan hasil yang baik saat sensor mendeteksi objek karena tidak adanya selisih yang dihasilkan pada 5 pengujian.

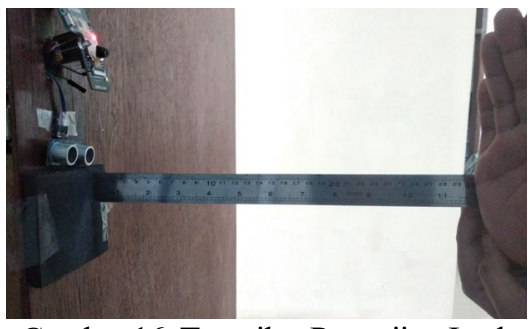

Gambar 16. Tampilan Pengujian Jarak

\subsection{Pengujian Software Sistem}

Penelitian ini menguji perangkat lunak sistem, tujuannya adalah untuk menyesuaikan website dengan browser, tujuannya untuk mengetahui apakah halaman website yang dibuat dapat menampilkan semua data sesuai dengan desain. Hasil uji kompatibilitas browser situs web ditunjukkan pada Tabel 5.

Tabel. 5 Pengujian Software

\begin{tabular}{|c|c|c|c|c|}
\hline \multirow{2}{*}{ No } & \multirow{2}{*}{ Aspek } & $\begin{array}{c}\text { Chrome } \\
\text { Version } \\
\text { 91.0.4472. }\end{array}$ & $\begin{array}{c}\text { Miscosoft } \\
\text { Edge } \\
\text { Version } \\
91.0 .864 .54\end{array}$ & $\begin{array}{c}\text { Mozilla } \\
\text { Firefox } \\
\text { Version } \\
89\end{array}$ \\
\hline 1 & $\begin{array}{c}\text { Halaman } \\
\text { Live } \\
\text { Streaming }\end{array}$ & $\sqrt{ }$ & $\sqrt{ }$ & $\sqrt{ }$ \\
\hline
\end{tabular}

Keterangan :

$\checkmark$ : Berhasil

$\mathrm{X}$ : Tidak Berhasil

Dapat dilihat hasil uji coba pada tabel 5 bahwa aplikasi yang dibuat dapat berjalan dengan baik pada web browser Google Chrome, Mozilla Firefox ,dan Microsoft Edge berfungsi dengan baik serta semua responsif dari aplikasi dan alat bisa berjalan dengan baik.

\section{KESIMPULAN DAN SARAN}

\subsection{Kesimpulan}

Berdasarkan hasil perancangan dan pengujian sistem secara keseluruhan, maka kesimpulan dari alat yang dibuat diuraikan sebagaimana berikut :

1. Berdasarkan langkah - langkah yang telah dilakukan bahwa sistem keamanan pintu kamar kos berhasil di rancang.

2. Berdasarkan hasil perancangan pada sistem keamanan pintu kamar kos terdapat peningkatan pada keamanan pada pintu kamar kos.

3. Berdasarkan hasil pengembangan pada monitoring berplatform aplikasi Telegram dan Website berhasil berjalan dengan baik.

4. Berdasarkan hasil dari pengujian pengguna menunjukan bahwa rata - rata responeden setuju dengan adanya sistem keamanan pintu kamar kos.

\subsection{Saran}

Dari hasil penelitian yang dilakukan oleh penulis, maka penulis menyarankan untuk pengembangan penlitian sebagai berikut:

1. Memerlukan cahaya yang terang untuk keberhasilan saat mendeteksi wajah.

2. Menambahkan catu daya cadangan agar sistem bisa tetap bekerja dengan baik jika terjadi pemadaman listrik.

3. Pengembangan untuk sistem monitoring keamanan menggunakan aplikasi berbasis mobile.

\section{DAFTAR PUSTAKA}

[1] M. A. Ramadhan. 2020. "Rancang Bangun Akses Pintu Gerbang Indekos Menggunakan EKTP (Elektronik Kartu Tanda Penduduk) 
Berbasis Mikrokontroller" Institut Teknologi

Nasional Malang.

[2] Dedy Irawan, J., Handoko, F. and Adriantatri, E., 2019. Ruang Kuliah Pintar Pemantau Tingkat Efektivitas Pembelajaran Yang Dapat Mendeteksi Mahasiswa Bosan Dan Mengantuk. In Seminar Nasional Inovasi dan Aplikasi Teknologi di Industri

[3] A. Setiawan, A. I. Purnamasari. 2019. "Pengembangan Smart Home Dengan Microcontrollers ESP32 Dan MC-38 Door Magnetic Switch Sensor Berbasis Internet of Things (IoT) Untuk Meningkatkan Deteksi Dini Keamanan Perumahan". STIMK IKMI Cirebon ISSN.2580-0760

[4] M. F. Wicaksono, M. D. Rahmatya. 2020. "Implementasi Arduino dan ESP32 CAM untuk Smart Home". Universitas Komputer Indonesia.

[5] K. Zuhri, A. Ihkwan. 2020. "Perancangan Sistem Keamanan Ganda Brangkas Berbasis Telegram Menggunakan Mikrokontroller ESP32-CAM". Universitas Mitra Indonesia ISSN.2745-8911.

[6] A. Lukman, J. G. Kolo, "A Smart Door Security-Based Home Automation System: An Internet of Things", Journal of Telecommunication", [Diakses 26 Maret 2021]

[7] A. Z. Hasibuhan, H. Harahap, Z. Sarumaha, "Penerapan Teknologi RFID Untuk Pengendalian Ruang Kelas Berbasis Mikrokontroler", Universitas Prima Indonesia (UNPRI) Medan e-ISSN.2541-2019
[8] Sutarno, "Identifikasi Ekspresi Wajah Menggunakan Alihragam Gelombang Singkat (WAVELET) Dan Jaringan Syaraf Tiruan Learning Vector Quantizations (LVQ), Jurusan Sistem Komputer Universitas Sriwijaya Indralay. ISSN.1979-2328.

[9] N. W. Marti, "Pemanfaatan GUI Dalam Pengembangan Perangkat Lunak Pengenalan Citra Wajah Manusia Menggunakan Metode Eigenface", Universitas Pendidikan Ganesha ISSN.1907-5022.

[10] Salamun, F. Wazir, "Rancang Bangun Sistem Pengenalan Wajah Dengan Metode Pripincal Compenent Analysis", Universitas Abdurrab Pekanbaru ISSN.2477-2062.

[11] F. Setiawan, E. S. Rahayu, "Sistem Security Door Lock Berbasiskan Gerakan dengan Pengiriman Gambar Menggunakan Internet of Things", Jurnal Teknologi 8 (1) 2020 34-35 Universitas Jayabaya e-ISSN.2654-8666.

[12] P. W. Purnawan, Y. Rosita, "Rancang Bangun Smart Home System Menggunakan NodeMCU ESP8266 Berbasis Komunikasi Telegram Messeger", Techno.COM, Vol. 18, No. 4, November 2019: 348-360, Universitas Budi Luhur.

[13] M. I. Kurniawan, U. Sunarya, R. Tullo, "Internet of Things: Sistem Keamanan Rumah Berbasis Raspberry Pi dan Telegram Messenger, ELKOMIKA Universitas Telkom ISSN.23388323. 